DOI : $10.14746 /$ rie.2017.11.33

\title{
Krzysztof Malinowski (red.), Polskie elity polityczne wobec sto- sunków z Niemcami w ramach Unii Europejskiej, Wydawnictwo Instytut Zachodni, Poznań 2017, ss. 292.
}

Problemy z jakimi zmaga się w ostatnim czasie Unia Europejska począwszy od kryzysu gospodarczego i finansowego, poprzez kryzys migracyjny skutkują głębokimi podziałami wśród państw członkowskich. Różnice stanowisk dotyczące sposobów przezwyciężania pojawiających się na ich tle kwestii spornych wpływają zarazem na relacje dwustronne, czego przykładem są stosunki polsko-niemieckie. Dobitnym tego potwierdzeniem jest kryzys migracyjny w UE, który ujawniając rozbieżne interesy obu państw wskazuje na głębokie różnice w ocenie źródeł kryzysu i mechanizmów jego zażegnania. Pojednanie, partnerstwo, współpraca, wspólnota interesów, zbieżność poglądów i stanowisk to kategorie, które charakteryzowały jeszcze nie tak dawno polsko-niemieckie relacje. Obecnie, w warunkach niezwykle ożywionej debaty publicznej są one kształtowane w dużej mierze przez pryzmat kryzysu migracyjnego i przeciwstawnych stanowisk, jakie reprezentują Polska i Niemcy w kwestii jego rozwiązania. Przy czym kryzys migracyjny jest istotnym, aczkolwiek nie jedynym czynnikiem, który determinuje współczesne polsko-niemieckie relacje.

Zespół autorski pod kierownictwem Krzysztofa Malinowskiego w pracy Polskie elity polityczne wobec stosunków z Niemcami w ramach Unii Europejskiej podjął się zbadania poglądów i opinii polskich elit politycznych na temat polsko-niemieckich relacji w ramach Unii Europejskiej. Opierając się na założeniu istnienia silnych korelacji pomiędzy zjawiskami i procesami, które towarzyszą funkcjonowaniu UE a polsko-niemieckimi stosunkami analizują poglądy i opinie, jakie formułują polskie elity polityczne na ich temat. Zawężając problem badawczy Autorzy zdecydowali się przeanalizować określone obszary tematyczne, w ich ocenie w sposób szczególny determinujące polsko-niemieckie stosunki, a mianowicie wizje przekształceń UE, politykę wschodnią UE, kwestie bezpieczeństwa oraz problematykę energetyczno-klimatyczną. Początek badań wyznacza kryzys finansowy w strefie euro (2009), kończy zaś pojawienie się kryzysu migracyjnego w UE (2015). Z uwagi na współczesny wymiar współpracy Polski i Niemiec, czynników implikujących poziom i intensywność wzajemnych odniesień ze wszech miar słuszne jest przeprowadzenie pogłębionej analizy przyczyn ich impasu. Wyróżnione przez Autorów obszary analizy odzwierciedlają z jednej strony, zróżnicowanie poglądów i stanowisk, jakie reprezentują oba państwa, z drugiej zaś, obrazują brak zgodności w ocenie charakteru polsko-niemieckich relacji pośród polskich elit politycznych. Równie ważna - co należy podkreślić - była dla Autorów recenzowanej publikacji ocena gotowości polskich elit politycznych do formułowania rekomendacji dla polskiej polityki wobec Niemiec.

Recenzowana publikacja z racji podjętej przez jej Autorów egzegezy sposobu postrzegania przez polskie elity polityczne roli Niemiec z perspektywy polskich interesów, przyczynić się może do zdiagnozowania czynników determinujących polsko-niemiecką współpracę. Przy czym podkreślić należy wielość czynników oddziaływujących na polsko-niemiecką współpracę, zarówno tych o zewnętrznej, jak i wewnętrznej naturze. $Z$ jednej strony kryzys zadłużenia w strefie euro, kryzys uchodźczy, konflikt na Ukrainie, Brexit, podziały wśród państw członkowskich UE, z drugiej zmiany na scenie politycznej w Polsce, wszystkie te uwarunkowania w sposób zasadniczy wpływają na polsko-niemiecką współpracę. Artykułowanie odmiennych postaw i interesów przez oba państwa, także w kontekście funkcjonowania UE utrudnia (co nie oznacza że uniemożliwia) wzajemne relacje. Percepcja stosunków Polski i Niemiec przez polskie elity polityczne i symboliczne z uwzględnieniem europejskich uwarunkowań stanowić 
może jeden z czynników objaśniających współczesne polsko-niemieckie relacje. Przy czym, jak zauważono powyżej, jest to tylko jeden z czynników determinujących politykę Polski wobec Niemiec i Niemiec wobec Polski.

Autorzy jako wyjściowe przyjęli założenie istnienia braku konsensu polskich elit politycznych w sprawie stosunków z Niemcami. W dużej mierze wynika to ich zdaniem z tego, że zróżnicowana pozostaje ocena zmieniającej się roli Niemiec w UE, ich pozycji, znaczenia i oddziaływania na procesy europejskie, co rzutuje jednocześnie na podejście do stosunków z Niemcami. Jak zauważa we Wstępie Krzysztof Malinowski świadczą o tym rejestrowane w debatach politycznych i opinii publicznej komentarze oraz poglądy oscylujące między akceptacją a krytyką aktywnej postawy Niemiec, jako lidera procesów w UE w kontekście występujących i prognozowanych wyzwań i zagrożeń. Ponadto podkreśla on, iż formułowanie opinii i poglądów na temat sensu i zakresu współpracy z Niemcami w ramach UE jest związane dyskursywnie z procesem uzgadniania przez elity polityczne definicji roli Polski w UE i szerzej w Europie.

Podkreślić należy - jako walor recenzowanej pracy - iż w prowadzonych badaniach odwołano się do dwóch ujęć klasyfikacyjnych elit, po pierwsze, odwołano się do kategorii elit politycznych i koncepcji elit symbolicznych. Jako reprezentantów elit politycznych rozumianych jako elity rządzące zakwalifikowano parlamentarzystów (posłowie do Sejmu RP i senatorowie, posłowie do Parlamentu Europejskiego) oraz przedstawicieli władzy wykonawczej. Przedmiotem badań uczyniono również część elit, odgrywającą relewantną rolę w procesie modelowania polityki zagranicznej, a mianowicie odgrywającą rolę inspirującą i formułującą poglądy i opinie elit politycznych, jak też rekomendującą określone rozwiązania dla decydentów. Stanowią oni elitę symboliczną. Założenie to jest szczególnie cenne, bowiem znaczenie obranej podgrupy elit symbolicznych (akademików i ekspertów) dla życia politycznego, a w szczególności kształtowania polityki zagranicznej państwa jest raczej rzadko przedmiotem refleksji badawczej. Tym samym również podkreślenie znaczenia i roli elity symbolicznej, w rozumieniu przyjętym przez Autorów stanowi jej walor.

Recenzowana praca składa się z dwóch zasadniczych części. Pierwsza obejmuje analizę dyskursu i składają się nań trzy artykuły. Pierwszy autorstwa Jacka Kubery Niemcy na forum parlamentu $w$ latach 2009-2015 dotyczy dyskursu elit politycznych wobec problematyki niemieckiej na forum polskiego parlamentu. Przedmiotem analizy są wypowiedzi przedstawicieli elit decyzyjnych (członków egzekutywy) i elit parlamentarnych (posłów i senatorów), zarówno na forum plenarnym, jak i w komisjach spraw zagranicznych. Analiza dyskursu parlamentarnego miała na celu sprawdzenie hipotezy na temat zmienności stanowisk głównych dominujących w dyskursie politycznym ugrupowań oraz występowania w pewnych kwestiach konsensusu o charakterze ponadpartyjnym. Co istotne, i co potwierdziła przeprowadzona analiza, Niemcy były w analizowanym okresie jednym z najczęściej pojawiających się państw w polskim dyskursie parlamentarnym. W opinii Jacka Kubery wynikało to m.in. z politycznej i gospodarczej siły Niemiec i ich bezpośredniego oddziaływania na polskie sprawy.

Krzysztof Malinowski w rozdziale Academia: Spór o sens stosunków Polski z Niemcami $w$ Europie analizuje dyskurs przedstawicieli środowiska akademickiego. Przywołany Autor uwzględnił dwa typy wypowiedzi, po pierwsze, politologów, których obszarem badawczym jest polska polityka zagraniczna i rola Polski w Europie, po drugie, środowiska niemcoznawczego, analizującego politykę Niemiec i stosunki polsko-niemieckie. Do analizy wykorzystał dorobek badawczy w postaci opracowań publikowanych w czasopismach naukowych czy monografiach o tematyce niemcoznawczej i politologicznej, a także opracowania o charakterze eseistycznym oraz różnego rodzaju formy publicystyczne (np. wypowiedzi, opinie czy komentarze prasowe). Przeprowadzona przez Autora egzegeza dyskursu środowiska akademickiego wobec zasadniczych kwestii z zakresu współpracy Polski i Niemiec prowadzi do ciekawych konkluzji, które stanowić mogą przyczynek do dalszych pogłębionych badań dotyczących zarówno polsko-niemieckich relacji, jak również niemieckiej i polskiej polityki europejskiej. 
Pierwszą część publikacji zamyka artykuł Ryszardy Formuszewicz zatytułowany Eksperci: diagnoza i prognoza stosunków z Niemcami w ramach Unii Europejskiej, który analizuje działalność ekspertów z dwóch kategorii ośrodków. Pierwszą grupę badanych ośrodków stanowiły instytucje finansowane zasadniczo ze środków budżetowych jako zaplecze eksperckie polskiej polityki zagranicznej. Do tej grupy zaliczono Ośrodek Studiów Wschodnich, Instytut Zachodni w Poznaniu, Polski Instytut Spraw Międzynarodowych. Drugą kategorię tworzyły instytucje przynależne do trzeciego sektora o zróżnicowanej formie prawnej i zróżnicowanym profilu i charakterze.

Jako szczególny walor należy podkreślić, iż uczestnicy projektu, który stał się podstawą do opracowania recenzowanej monografii, realizując zamysł badawczy, zastosowali podwójne podejście badawcze do rekonstrukcji oraz wyjaśnienia stanowisk i poglądów polskich elit politycznych na temat stosunków Polski z Niemcami w ramach UE. Badania elit w wybranych segmentach (elity polityczne jako elity parlamentarne i elity symboliczne - akademicy i eksperci) odwoływały się do analizy dyskursu oraz wywiadów indywidualnych, ankiet i panelu fokusowego. Grupa obserwacji w przypadku anonimowych badań ankietowych objęła przedstawicieli elit politycznych - obecnych i byłych parlamentarzystów: posłów do Sejmu RP i członków Senatu RP oraz posłów do Parlamentu Europejskiego. Rezultat powyższego zamysłu badawczego prezentuje druga część recenzowanej monografii zawierająca wnioski dotyczące prowadzonych badań pogłębionych. Ta część monografii obejmuje dwa artykuły, pierwszy autorstwa Michała Nowosielskiego Parlamentarzyści wobec stosunków Polski z Niemcami oraz drugi autorstwa Marcina Tujdowskiego Eksperci wobec stosunków Polski z Niemcami (raport z wywiadów pogłębionych).

Recenzowana monografia jest ze wszech miar udaną próbą analizy poglądów polskich elit politycznych na problematykę stosunków Polski i Niemiec, akcentującą najważniejsze z punktu widzenia współpracy problemy. Co ważne, lokują je w kontekście Unii Europejskiej i uwzględniają zróżnicowany charakter czynników determinujących jej funkcjonowanie. Zamysł ten pozwala na szerszą analizę problemu i wykazania siły oddziaływania UE na polsko-niemiecką współpracę. Autorzy formułują interesujące wnioski, które stanowić mogą przyczynek do dalszych, pogłębionych analiz.

Reasumując, monografia przygotowana przez zespół autorski pod kierunkiem Krzysztofa Malinowskiego Polskie elity polityczne wobec stosunków z Niemcami w ramach Unii Europejskiej koncentruje się na istotnych kwestiach dotyczących badania elit politycznych, w szczególności ich stosunku do polsko-niemieckiej współpracy. Wnioski, jakie formułują badacze na podstawie przeprowadzonych badań, uzupełniają dotychczasową wiedzę dotyczącą czynników kształtujących ten fragment polityki zagranicznej państwa. Recenzowana praca to interesujące studium percepcji współpracy polsko-niemieckiej z perspektywy polskich elit politycznych i symbolicznych. Przydatna zarówno dla teoretyków, jak i praktyków na co dzień zajmujących się modelowaniem i realizowaniem polityki zagranicznej. Ze wszech miar jest godna polecania studentom stosunków międzynawowych, politologii, socjologii, dziennikarstwa i komunikacji społecznej, którzy po jej lekturze poszerzą swoją wiedzę i rozumienie czynników determinujących polsko-niemieckie relacje. 